\title{
Engineering of Rocking Nut Maker Tools
}

\author{
Sulharman $^{1}$
}

\begin{abstract}
There had been mechanically conducted an engineering of Rocking Nut Maker Tools for rocking nut small industry. The objective is to engineer a maker tool for rocking nut which can work with the assistance of motor without using manpower, thus it will increase the production of rocking nut. Making method on rocking nut maker tool includes: (1) Designing tool; (2) tool making; (3) Tool testing. According to the result of engineering tool, there were obtained: frame for tray that was made from angle iron: the height was $450 \mathrm{~mm}$, the length was $1500 \mathrm{~mm}$, and the width was $500 \mathrm{~mm}$ width, while the thickness was $3 \mathrm{~mm}$. The tray was made from aluminium with $60 \mathrm{~mm}$ height, $1485 \mathrm{~mm}$ length, $485 \mathrm{~mm}$ width and $3 \mathrm{~mm}$ plate thickness. The motor had the power capacity of $1 / 2 \mathrm{HP}$, single phase and $1400 \mathrm{rpm}$ while gearbox was $1: 10$. The wheels were made from iron with the diameter of $60 \mathrm{~mm}$ and the thickness of $20 \mathrm{~mm}$. There are 4 wheels which were installed under the tray. Popper mechanism was made from iron that included iron plate with the diameter of $210 \mathrm{~mm}$, the thickness of $7 \mathrm{~mm}$ and iron bar with the diameter of $15 \mathrm{~mm}$ and the length of $220 \mathrm{~mm}$. This was equipped with speed variable. The result from tools performance could increase the production capacity by $400 \%$; the bumpy texture on peanut surface could attach more strongly, the storage capacity increased for 6 months, while the production only lasted for 3 months if it was by manual. The capacity of rocking nut maker was $45 \mathrm{~kg} / \mathrm{day}$; it was only $7.5 \mathrm{~kg} / \mathrm{day}$ by manual. The average time consumed for rocking nut making was 1.5 hours/ processing, while by manual was 3 hours/ processing. The rocking speed was 89-99rpm. This was an economical technology, by using this engineered tool, the production capacity per month was increased by $750 \mathrm{~kg}$ or equivalent with $\mathrm{Rp} .47,250,000$.- and by using this tool, there was an increase in profit of Rp. 13,450/ kg while by manual was only $R p 2,250 / \mathrm{kg}$. On the other side, the production cost by using tools was Rp 51 , $550 / \mathrm{kg}$, while by manual was Rp. $72.750 / \mathrm{kg}$.
\end{abstract}

Keywords — engineering tools, performance, rocking nut.

Abstrak-Telah dilakukan rekayasa alat pembuat kacang goyang secara mekanis untuk industri kecil kacang goyang.Tujuannya adalah merekayasa suatu alat pembuatan kacang goyang yang dapat bekerja tanpa banyak menggunakan tenaga manusia dengan bantuan motor penggerak sehingga produksi kacang goyang meningkat. Metode pembuatan alat pembuat kacang goyang, meliputi : (1) mendesain alat, (2) pembuatan alat, (3) menguji alat. Berdasarkan hasil rekayasa alat diperoleh ; rangka untuk nampan terbuat dari besi siku : tinggi $450 \mathrm{~mm}$, panjang $1500 \mathrm{~mm}$, lebar 500 mm dan tebal $3 \mathrm{~mm}$. Nampan terbuat dari aluminium dengan tinggi $60 \mathrm{~mm}$, panjang $1485 \mathrm{~mm}$, lebar $485 \mathrm{~mm}$ dan tebal plat $3 \mathrm{~mm}$. Motor dengan daya 1/2 HP, 1 phasa dan $1400 \mathrm{rpm}$ sedangkan gearbox 1:10. Roda terbuat dari besi dengan diameter $60 \mathrm{~mm}$ dan tebal $20 \mathrm{~mm}$. Roda berjumlah 4 buah yang dipasang pada bagian bawah nampam. Mekanisme penggoyang terbuat dari besi yang terdiri dari piringan besi dengan diameter $210 \mathrm{~mm}$, tebal $7 \mathrm{~mm}$ dan batang besi dengan diameter $15 \mathrm{~mm}$ dan panjang $220 \mathrm{~mm}$. Dilengkapi dengan variable speed. Hasil unjuk kerja alat dapat meningkatkan kapasitas produksi sebesar $\mathbf{4 0 0 \%}$, duri pada permukaan kacang melekat lebih kuat dan daya simpan meningkat lebih lama 6 bulan sedangkan produksi manual hanya 3 bulan. Kapasitas alat pembuatan kacang goyang 45 kg/hari. Waktu pembuatan kacang goyang rata-rata 1,5 jam/proses sedangkan secara manual 3 jam/proses. Kecepatan penggoyangan 89 99 rpm. Tekno ekonomi, dengan alat hasil rekayasa ada kenaikan kapasitas per bulan $750 \mathrm{~kg}$ atau sebesar Rp. 47.250.000,.serta laba dengan menggunakan alat naik menjadi Rp.13.450/kg sedangkan secara maual Rp. 2.250/kg. Sedangkan biaya produksi menggunakan alat Rp. 51.550/kg dan Rp. 72.750/kg secara manual.

Kata Kunci-rekayasa alat, unjuk kerja, kacang goyang.

\section{INTRODUCTION}

$\mathrm{R}$ ocking nut (kacang goyang) is one of traditional foods from North Sulawesi which is well-known outside of North Sulawesi. In East Kalimantan some people also work on it.

Rocking nut is made from peanut coated by sugar with or without using food coloring. It has distinctive shape (the texture is bumpy) obtained from particular process. It is processed with simple technology, from the ingredients preparation, production process until the product packaging [1].

In the production process, a tray from bamboo skin is used as the container/cooking tool and shaper of rocking nut. Some type of bamboo has the tensile strength of 480 $\mathrm{MPa}$, which is equivalent to 12 tons/m2, exceeding the tensile strength of medium-grade steel which is only 370

${ }^{1}$ Sulharman are with Institute for Research and Standardization of Industry of Samarinda, Ministry of Industry of the Republic of Indonesia,75124, Indonesia. Email: sulharman@kemenperin.go.id.
MPa. Besides, bamboo has a weakness that requires our ability to handle it, namely: Susceptible to weathering, decrepit, not fireproof and not waterproof. Thus, the bamboo must be positioned in a place that is not moist. It must not get burned too. The bamboo is also prone to fungal pest, mildew, termites, powder, and the likes, so that its age is relatively short [2].

As the heat source, a kerosene/LPG stove is used. The upper part of the stove, which is the flame, is coated with zinc to prevent direct contact between fire and the tray.

Peeled peanuts are put into a tray that is hung (the both sides are tied on a wooden frame). On the upper part of winnow, there is sugar water which is contained into plastic bottles or coconut shells whose the bottom part is perforated, so that the sugar water will drip continuously during the roasting. The sugar water is colored with food coloring.

During production process, the tray is hung on the rope, and rocked by the operator while it is being heated by fire stove. This process takes approximately 3 hours until all surfaces of peanuts are coated with sugar water and becoming bumpy. By using this method, the 
production capacity is only $9 \mathrm{~kg} / \mathrm{day}$. Therefore, a rocking tool which could ease manpower needs to be engineered.

The purpose of this research was to engineer a rocking nut maker which could automatically rock without manpower with support of motor. The objective was to increase production capacity of rocking nut.

\section{METHOD}

The research was conducted at workshop with these following stages; tool designing, preliminary test, and primary test.

\section{A. Materials and Tools}

The materials which are used were gearbox, motor $1 / 2$ HP, Angle iron $5 \times 5$, aluminium plate, switch, cable, electrical socket, bolt, cable terminal, grinder, welding electrode, paint, thinner. While the materials for experiment were peanuts, sugar, and food coloring. The tools that were used in this research were gauge, caliper, weigher, stopwatch, welding machine, drilling machine, grinder machine.

\section{B. Working Stage}

Design approach of rocking nut maker tool comprised of frame for tray, which was the main frame to support tray, then the tray to contain peanuts. The mechanism of rocking machine was to rock the tray and sugar water container.

The working principle of rocking nut maker tool was: the peeled peanuts were put into the tray, then pour the sugar water that had been colored with food coloring to the bottles over the tray (there were three bottles) which were hung on the bottle hanger pole. After that, stoves under the tray (three stoves) were turned on. Then, the motor which was connected by iron bar to the tray was turned on, thus the tray can be rocked to the left and to the right.

The functional design was: frame for the tray that functioned to support the tray and made it remained on its position. Frame for the tray also functioned as the mounting for motor, gearbox and wheel. The pivot of gearbox is connected to iron bar to the tray's side, thus tray could be rocked to the left and to the right. Between the frame and tray there is a wheel to rock the tray to the left and to the right. The function of tray is to contain the roosted peanuts. Rocking mechanism is to rock the tray to the left and to the right which comprised of iron plate, iron bar, motor, and gear box. Sugar water hanger was functioned to hang bottles of sugar water.

\section{Design of Rocking Nut Maker}

Structural design; frame for the tray was made from angle iron with the length, width, height, thickness of $(1500 ; 500 ; 450 ; 3) \mathrm{mm}$. The detailed frame design for the tray is shown on Figure 1 and Figure 2. The tray was made from aluminium with length, width, height and thickness of $(1485 ; 485 ; 60 ; 3) \mathrm{mm}$. The detail of frame was shown on Figure 3 and Figure 4.

The motor had power capacity of $1 / 2 \mathrm{HP}$, single-phased and $1400 \mathrm{rpm}$, while 1: 10 gearbox could be seen on Figure 5. The wheel was made from iron with diameter of $60 \mathrm{~mm}$ and thickness of $20 \mathrm{~mm}$. There were 4 wheels that were installed on the bottom part of tray. The detailed size could be seen on Figure 6 and Figure 7.
Rocking mechanism was made from iron that comprised of iron plate with diameter of $210 \mathrm{~mm}$, thickness of $7 \mathrm{~mm}$, and iron bar with diameter of $15 \mathrm{~mm}$ and lenght of $220 \mathrm{~mm}$. For the detailed size may be seen on Figure 8.

Hanger of sugar water was made from iron with 200 $\mathrm{mm}$ length, $1300 \mathrm{~mm}$ height and $10 \mathrm{~mm}$ thickness. The detailed size could be looked at Figure 9 and Figure 10.

\section{Testing Design}

After the tool was completed, the tool testing was conducted by: weighing the peanuts and then putting it into the tray, after that, turn on the motor to rock the peanuts and record that rocking time. After it had been completely processed, peanuts were removed from the pan and then the peanuts were weighed.

Do these steps for several times, and pay attention to whether the final result are the bumpy textured peanuts.

\section{E. Preliminary Testing}

The objective of preliminary testing was to examine tool's performance after being completed. From this examination, there obtained the accurate motor rotation, thus the peanuts will not be spilt out of the pan during rocking process.

\section{F. Primary Testing}

This referred to the test whose goal was to find the whole performance of rocking nut maker tool such as tool capacity and time for rocking nut making.

\section{RESULTS AND DISCUSSIONS}

At the preliminary testing, the tools could work well. It obtained the correct motor rotation of 89- 99 rpm. From this preliminary testing result, evidently, the bumpy texture was shaped on the peanuts surface much faster (15-20 minutes), while while if we use bamboo winnowing tray, it would take longer time (25-30 minutes). The bumpy texture were shaped faster because aluminium naturally delivers heat much better than bamboo does. The shaping of bumpy texture is shown on Figure 11.

The test result of the performance of rocking nut maker tools was shown on the Table 1 .

Based on the table above, the peanut weight was $2.5 \mathrm{~kg}$ for each tray with the average time of 1.5 hours for rocking nut making. The net weight of rocking nut was $2.75 \mathrm{~kg} /$ tray or $8,25 \mathrm{~kg}$ for a process of rocking nut making.

At the $89-99 \mathrm{rpm}$ of motor rotation, the rocking did not spill the peanuts from tray. The comparison results of manual and engineered tools could be seen on table 2 .

The table above shows the comparison results of manually kacang goyang making with engineered rocking nut maker. The capacity of manually rocking nut making by using bamboo tray was $1.5 \mathrm{~kg}$, while the result of engineered rocking nut maker tools was 7.5, so the result was increased by $6 \mathrm{~kg}$. One process of rocking nut manual making required up to 2 people, while using engineered tool only required one operator.

This engineering of rocking nut maker tools had 3 trays because the existing production of rocking nut had 3 
colors, so it could produce 3 different colors of rocking nut in one making process. The maker tools capacity of rocking nut was $7.5 \mathrm{~kg}$.

Aluminium materials were selected for the tray because it is naturally easy to fabricate, good conductor (thermal conductivity $=237 \mathrm{~W} \mathrm{~m}^{\circ} \mathrm{K}$ ), corrosion resistance, light density (only $2.7 \mathrm{~g} / \mathrm{cm}^{3}$, while the iron $\pm 8.1 \mathrm{~g} / \mathrm{cm}^{3}$ ) [3]. Meanwhile, the thermal conductivity of bamboo was only $0.14-0.14 \mathrm{~W} / \mathrm{m}^{\circ} \mathrm{K}[4]$.

The bumpy texture of peanut surface was attached more strongly and the resistance to open air had longer periods (6 months) if it was compared to the manual method which only lasted for 3 months. The average time consumed for rocking nut making was 1.5 hours. The rocking speed was 89-99 rpm.

A comparison of these tools with other tools is a tool has a capacity of $7.5 \mathrm{~kg}$ /process during 1.5 hours by 88 $99 \mathrm{rpm}$ whereas other tools have a capacity of 3.2 $\mathrm{kg} /$ process for 1 hour with $5 \mathrm{rpm}$ and jolt at this tool needs to be reduced [1]. UD. Serasi Kotamobagu have a capacity of $1 \mathrm{~kg} /$ process for 1 hour with manual opration [5]. As for the other devices design tools trays from woven stainless steel plate with a production capacity of approximately $7.5 \mathrm{~kg}$, peanuts rocking without motor movers [6].

\section{A. Economical Technology (Comparison of the manual tool and the engineered tool)}

This is economical technology with the calculation of 20 performance days. The comparison used the engineered tool and manual tool.

Based on the calculation in the table above, there was difference in capacity per month of $750 \mathrm{~kg}$ or Rp.47,250,000- . There was an increase in capacity by $400 \%$. Concerning of the selling price, rocking nut had different price per $\mathrm{kg}$ because if using manual tool, there must be any reimbursement cost of tray (after only 3 times of rocking nut making, the winnow was burnt and must be replaced by the new one), while by using engineered tool, there did not need any reimbursement cost for tray. It was because the tray of engineered tools was made from alumunium, thus thus saving labor, time and fuel costs.

\section{CONCLUSION}

From the implemented design and testing, some conclusions could be drawn as the followings:

1. The rocking nut maker tools consist of; Frame for tray was made from angle iron: the length, width, height and thickness were $(1500 ; 450 ; 500$; and 3 ) $\mathrm{mm}$ respectively. The tray was made from aluminium with the length, width, height and thickness of (1485; 485 ; 60 ; and 3 ) $\mathrm{mm}$ respectively. The motor had power capacity of $1 / 2 \mathrm{HP}$, single-phased and $1400 \mathrm{rpm}$ while gearbox was $1: 10$. The wheels were made from iron with the diameter of $60 \mathrm{~mm}$ and the thickness of $20 \mathrm{~mm}$. There were 4 wheels which were installed at the bottom part of tray. Rocking mechanism was made from iron that included iron plate with the diameter of $210 \mathrm{~mm}$, the thickness of $7 \mathrm{~mm}$ and iron bar with the diameter of $15 \mathrm{~mm}$ and the length of $220 \mathrm{~mm}$. This was equipped with speed variable.

2. The period and capacity of engineered tool could increase because the material of the tray was made from aluminium which was a naturally better conductor $\left(\mathrm{k}=237 \mathrm{~W} / \mathrm{m}^{\circ} \mathrm{K}\right)$ compared to the tray made from bamboo $\left(\mathrm{k}=0.14-0.14 \mathrm{~W} / \mathrm{m}^{\circ} \mathrm{K}\right)$. The average time consumed for kacang goyang making was 1.5 hours/processing. While the manual production spent 2 hours/processing and the rocking speed was 89-99 rpm.

3. This tool operation was so easy, it was just by turning on the stove and putting the roasted peanut into each of trays, then turning on the rocking motor by pressing the button "On" on the switch of speed control switch.

4. This is Economical technology, the result of engineered tools showed some increase in capacity by $400 \%$, with the capacity difference per month was $750 \mathrm{~kg}$ or by Rp. 47.250.000,-

5. Rocking nut that is produced by using engineered result tools was crispier than by the result of using manual tool. And the storability was 6 months longer than manual production which was only 3 months.

6. This tool doesn't have a jolt like that owned Balai in Manado [5] so votes loud and not inflicted this tool has gained a patent with no. P00201300198.

\section{Suggestion}

These tools can also be used to making kacang atom, kacang kentucky and coated peanuts.

\section{ACKNOWLEDGMENT}

To Institute for Research and Standardization of Industry of Samarinda that have financed this observation, "Mekar" repair shop in Samarinda that have helped in fabrication of these tools, and rocking nut "Cici" in Tenggarong which has utilized these tools since 2010 until now.

\section{REFERENCES}

[1] Rumajar Hasera, "Rekayasa Teknologi Semi Mekanis untuk Pembuatan Kacang Goyang," Balai Riset dan Standardisasi Industri Manado, Manado, 2000.

[2] Mba Ari, "Property Today Inc. - Mengenal Karakteristik Bambu sebagai Alternatif Bahan Bangunan," Property Investment \& Developer, [Online]. Available: http://propertytoday.co.id/mengenal-karakteristik-bambu-sebagaialternatif-bahan-bangunan.html. [Accessed 7 July 2015].

[3] Wikipedia, "Wikipedia The Free Encyclopedia- Aluminium," Free Encyclopedia, [Online]. Available: https://id.wikipedia.org/wiki/Aluminium. [Accessed 25 January 2015].

[4] Aliexpress, "Aliexpress," Online Shopping Website, [Online]. Available: http://id.aliexpress.com/item/Top-grade-bamboo-palletfor-block-making-machine/32298955507.html. [Accessed 25 January 2015]

[5] M. Aditya, "Analisis Supply Chain dan Keuntungan Industri Kacang Goyang Ud. Serasi Kotamobagu," Cocos Jurnal Ilmiah Fakultas Pertanian Universitas Sam Ratulangi, vol. 1, no. 1, pp. 1$15,2012$.

[6] A. L. Ola, M. Nasibu and S. H. Widardo, "Engineering of Processed Bean Equipment," Oct 1998. [Online]. Available: http://agris.fao.org/agris- 
search/search.do?recordID=ID2000001235. [Accessed $6 \quad$ Feb 2016].

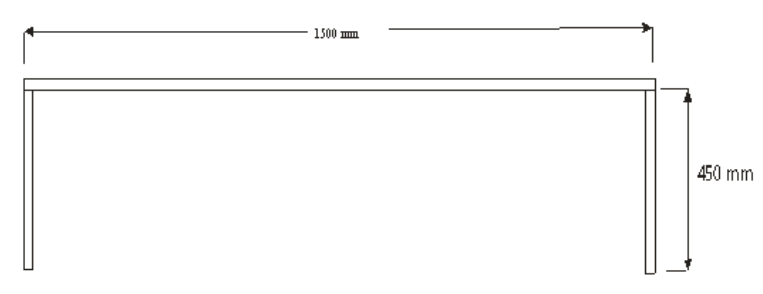

Figure 1. Frame for tray looks ahead

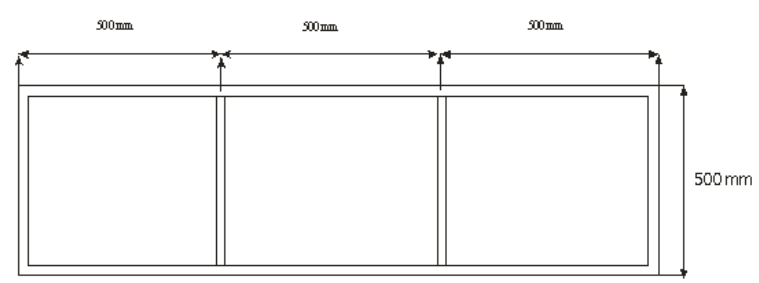

Figure 2. Frame for tray looks over

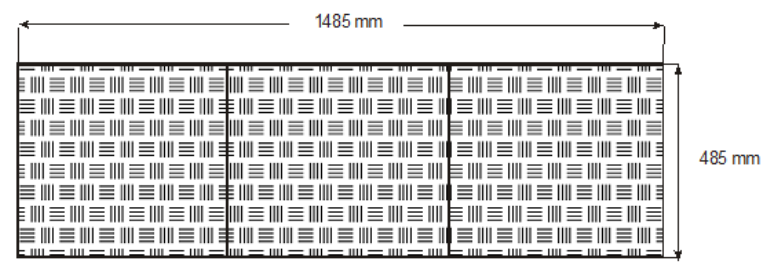

Figure 3. Tray looks over
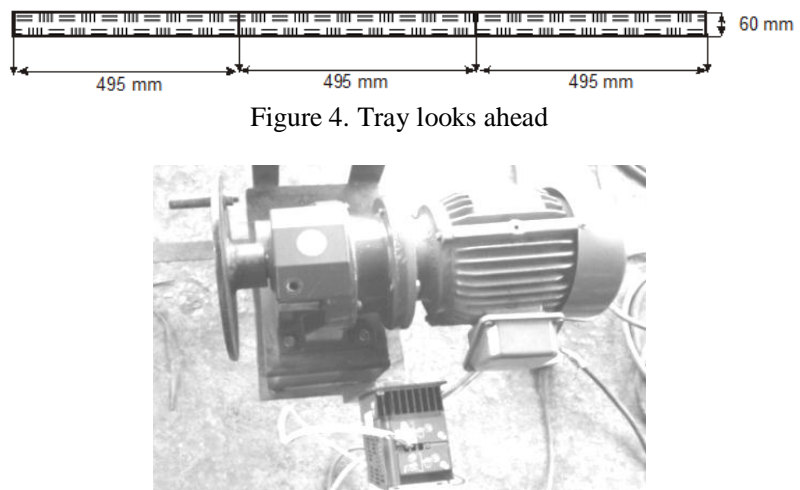

Figure 5. Motor and Gearbox

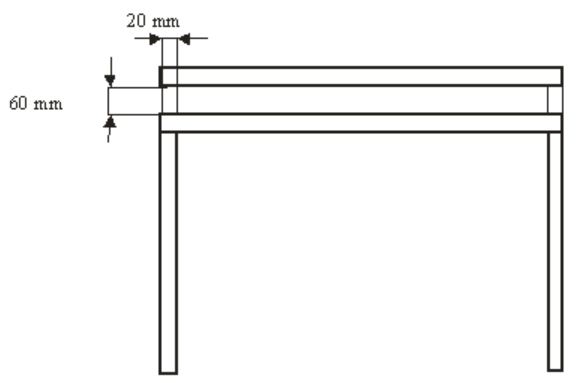

Figure 6. Wheels side view

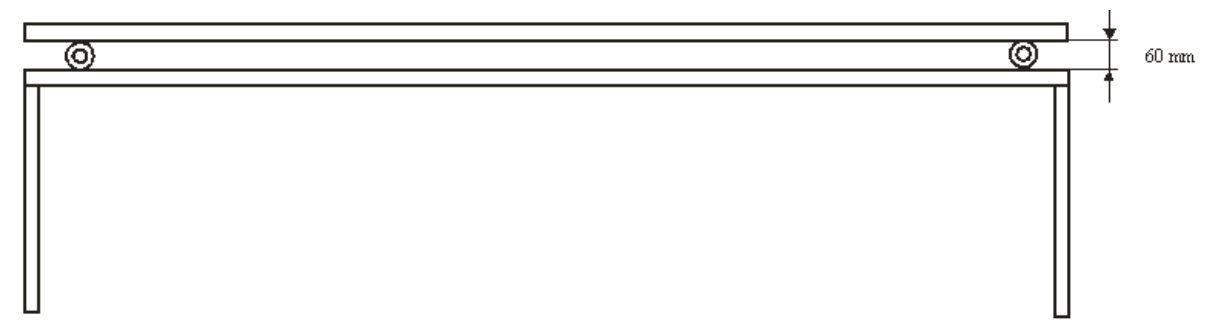

Figure 7. Wheels front views

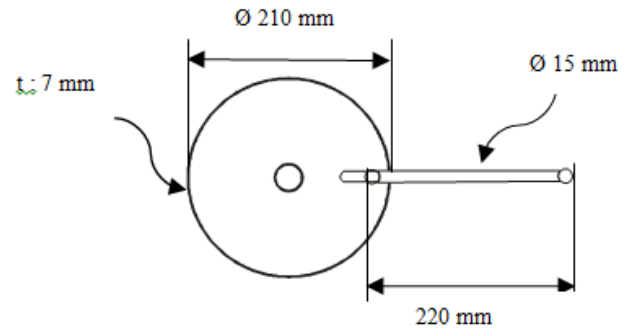

Figure 8. Rocking mechanism

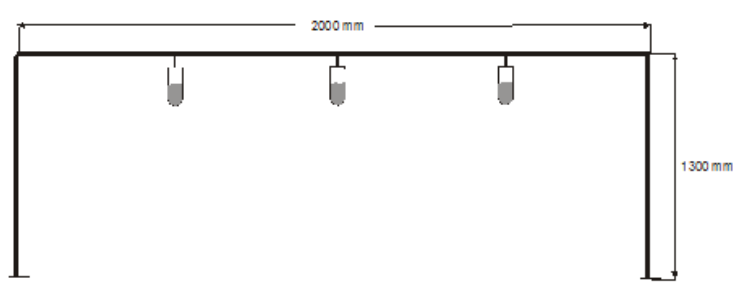

Figure 9. Place sugar water front view

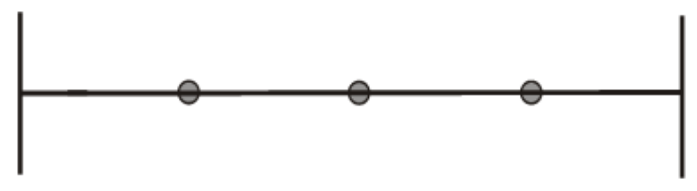

Figure 10. Place sugar water looks over

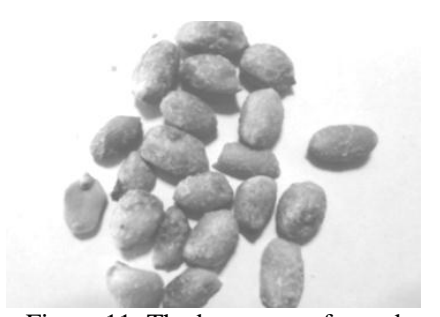

Figure 11. The bumpy are formed

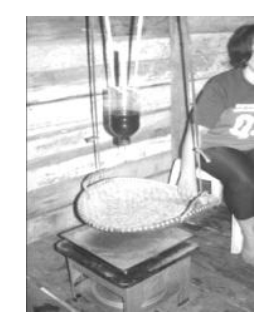

Figure 12 . The process of making rocking nuts manually

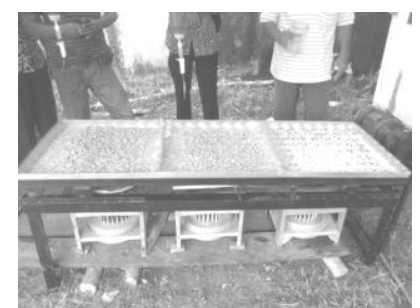

Figure 13. The process of making rocking nuts mechanically 
TABLE 1.

THE RESULT OF PERFORMANCE TESTING TOOL MANUFACTURURE ROCKING NUT

\begin{tabular}{|c|c|c|c|c|c|c|c|}
\hline \multirow[t]{2}{*}{ Repetition } & \multicolumn{3}{|c|}{ Weight Nuts } & \multicolumn{3}{|c|}{$\begin{array}{l}\text { Rocking nuts weight after the process is } \\
\text { complete }\end{array}$} & \multirow[t]{2}{*}{ Time } \\
\hline & 1 & 2 & 3 & 1 & 2 & 3 & \\
\hline 1 & $2,5 \mathrm{~kg}$ & $2,5 \mathrm{~kg}$ & $2,5 \mathrm{~kg}$ & $2,75 \mathrm{~kg}$ & $2,75 \mathrm{~kg}$ & $2,75 \mathrm{~kg}$ & $1: 31$ \\
\hline 2 & $2,5 \mathrm{~kg}$ & $2,5 \mathrm{~kg}$ & $2,5 \mathrm{~kg}$ & $2,75 \mathrm{~kg}$ & $2,74 \mathrm{~kg}$ & $2,75 \mathrm{~kg}$ & $1: 31$ \\
\hline 3 & $2,5 \mathrm{~kg}$ & $2,5 \mathrm{~kg}$ & $2,5 \mathrm{~kg}$ & $2,74 \mathrm{~kg}$ & $2,75 \mathrm{~kg}$ & $2,75 \mathrm{~kg}$ & $1: 30$ \\
\hline Average & & & & $2,75 \mathrm{~kg}$ & $2,75 \mathrm{~kg}$ & $2,75 \mathrm{~kg}$ & $1: 30$ \\
\hline
\end{tabular}

TABLE 2.

COMPARISON OF MANUFACTURING ROCKING NUT MANUALLY AND TOOL ENGINEERING

\begin{tabular}{ccc}
\hline Performance Tool & Making rocking nuts manually & $\begin{array}{c}\text { The manufacture of rocking nuts with } \\
\text { the engineering tool }\end{array}$ \\
\hline Capasity & $1,5 \mathrm{~kg}$ & $7,5 \mathrm{~kg}$ \\
Time & 3 hours & 1,5 hours \\
LPG & $2 \mathrm{~kg}$ & $1 \mathrm{~kg}$ \\
Operator & $1-2$ person & 1 orang \\
\hline \hline
\end{tabular}

